\title{
ATMOSPHERIC PM 10 PARTICLE CONCENTRATION MEASUREMENTS AT CENTRAL AND PERIPHERAL URBAN SITES IN ATHENS AND THESSALONIKI, GREECE
}

\author{
P.D. KALABOKAS ${ }^{1, *}$ \\ A.D. ADAMOPOULOS ${ }^{2}$ \\ L.G. VIRAS ${ }^{2}$
}

\author{
${ }^{1}$ Academy of Athens, Research Center for Atmospheric \\ Physics and Climatology, \\ 131, Tritis Septemvriou, str., 11251 Athens, Greece \\ ${ }^{2}$ Ministry for the Environment, Energy and Climatic Change, \\ Directorate of Air Pollution and Noise Control, \\ 147, Patission str., 11251 Athens, Greece
}

Received: 18/12/09

Accepted: 16/02/10

\begin{abstract}
The analysis of the $\mathrm{PM}_{10}$ particle measurements at the two major urban areas of Greece, Athens and Thessaloniki, showed that the mean monthly $\mathrm{PM}_{10}$ concentrations at the central urban stations, are on the average about twice as high than the corresponding ones at the examined peripheral stations. The distribution of the daily $\mathrm{PM}_{10}$ values shows significant violations of the EU air quality standards, especially in the central urban stations. At the peripheral stations comparable distributions of $\mathrm{PM}_{10}$ concentration values are found. The highest $\mathrm{PM}_{10}$ hourly values are recorded at the central urban stations during the cold semester of the year and during the morning hours. The scatter-plot diagrams of the central urban daily $\mathrm{PM}_{10}$ mean values versus the peripheral stations show important influence of the regional aerosol episodes on the measured $\mathrm{PM}_{10}$ concentrations in the urban areas of Athens and Thessaloniki, which is stronger in Athens and during the warm semester of the year. The $\mathrm{PM}_{10}$ diurnal variation pattern are quite similar with the corresponding variations observed for primary urban pollutants, like the morning and the evening peaks, but also at the peripheral stations exhibit a broad mid-day peak indicating elevated rural background $\mathrm{PM}_{10}$ levels. Additional daily measurements at the rural station of Aliartos in Central Greece give $\mathrm{PM}_{10}$ average values around $30 \mu \mathrm{g} \mathrm{m}^{-3}$, comparable to the corresponding average $\mathrm{PM}_{10}$ values of the peripheral stations in Athens and Thessaloniki. Such high rural background $\mathrm{PM}_{10}$ daily mean values could lead to average annual values higher than the corresponding $E U \mathrm{PM}_{10}$ standard $\left(40 \mathrm{\mu g} \mathrm{m}^{-3}\right)$ and should be taken into account in the formulation of the local pollution abatement strategies as they represent about the half of the average $\mathrm{PM}_{10}$ levels measured at the central urban stations of both examined urban areas.
\end{abstract}

KEYWORDS: Air pollution, Urban $\mathrm{PM}_{10}$ concentrations, $\mathrm{PM}_{10}$ rural background, Athens, Thessaloniki, Aliartos, Greece.

\section{INTRODUCTION}

Atmospheric aerosols can be either primary (directly emitted into the atmosphere) or secondary (formed in the atmosphere from the transformation of other atmospheric constituents acting as precursors). The sources of atmospheric particles can be either anthropogenic or natural (Finlayson-Pitts and Pitts, 2000; Warneck, 2000; Buseck and Schwartz, 2006). The ambient atmospheric particles may have a negative impact on human health and the first indications on that have been reported in the early 1950s (Lippman, 1989). Over the last two decades many epidemiological studies conducted in many countries around the world observed associations between ambient particle concentrations (especially $\mathrm{PM}_{10}$ and $\mathrm{PM}_{2.5}$ ) and human health risks (e.g. Dockery et al., 1992; Katsouyanni et al., 1997). The 
European Union set in 1999 air quality standards for $\mathrm{PM}_{10}$ particles. The annual average value should not exceed $40 \mu \mathrm{g} \mathrm{m}^{-3}$ and the $50 \mathrm{\mu g} \mathrm{m}^{-3}$ daily average value must not be exceeded more than 35 times during the year (EC, 1999; Schwela et al., 2002).

The Athens and Thessaloniki urban areas in Greece are facing air pollution problems during the last decades (Viras and Siskos, 1992; Mantis et al., 1992; Kassomenos et al., 1995; Ziomas, 1998; Kalabokas et al., 1999; Kelessis et al., 2002; Kourtidis et al., 2002). In recent years, the most serious air pollution problems in both urban areas are related to surface ozone but also to the $\mathrm{PM}_{10}$ particles air concentrations as violations of the EU standards of atmospheric $\mathrm{PM}_{10}$ particles are quite frequently recorded immediately after the start of their measurement; 1989 for Thessaloniki and 2001 for Athens (MinEnv report, 2002; Kelessis et al., 2002; Chaloulakou et al., 2003; Chaloulakou et al., 2005; Kelessis et al., 2006). The $\mathrm{PM}_{10}$ levels measured at both urban areas are among the highest recorded in Europe (EEA report, 2006). The meteorological conditions prevailing in coastal urban areas with intense primary pollutant emissions such as the examined cities might deteriorate the air quality and lead to serious air pollution episodes (Helmis et al., 1997; Kassomenos et al., 1998; Flocas et al., 2009)

In this work the measurements of suspended $\mathrm{PM}_{10}$ particles in two monitoring stations in Athens and two monitoring stations in Thessaloniki with different site characteristics (central urban and peripheral) are examined, during the 4-year period 2001-2004. The regional $\mathrm{PM}_{10}$ background levels in the area will be also examined, based on the data analysis of the peripheral stations at both cities and also on the $\mathrm{PM}_{10}$ measurements carried out at the rural station of Aliartos in Central Greece.

\section{EXPERIMENTAL}

The central urban monitoring stations, located close to intense urban emissions are Aristotelous in Athens and Agia Sophia in Thessaloniki. The peripheral stations, located at the edges of the respective urban areas are Thrakomakedones in Athens and Panorama in Thessaloniki. In Athens, Aristotelous station ( $\left.23^{\circ} 43^{\prime} 40^{\prime \prime} \mathrm{N}, 37^{\circ} 59^{\prime} 18^{\prime \prime} \mathrm{E}\right)$ is located at the city center (95 m altitude) while the Thrakomakedones peripheral station $\left(23^{\circ} 45^{\prime} 29^{\prime \prime} \mathrm{N}, 38^{\circ}\right.$ $08^{\prime} 37^{\prime \prime} \mathrm{E}$ ) is located $12 \mathrm{~km}$ to the $\mathrm{N}$ of the city center at $550 \mathrm{~m}$ altitude. In Thessaloniki, the Agia Sophia station $\left(22^{\circ} 56^{\prime} 34^{\prime \prime} \mathrm{N}, 40^{\circ} 37^{\prime} 38^{\prime \prime} \mathrm{E}\right)$ is located at the center of the city ( $20 \mathrm{~m}$ altitude) while the Panorama station ( $\left.23^{\circ} 01^{\prime} 54^{\prime \prime} \mathrm{N}, 40^{\circ} 35^{\prime} 20^{\prime \prime} \mathrm{E}\right)$ is located $7 \mathrm{~km}$ SE from the city center at $330 \mathrm{~m}$ altitude. All these stations are part of the National Air Pollution Monitoring Network (NAPMN). The particulate monitors performing real time measurements of the ambient dust concentration utilize the radiometric principle of beta attenuation by a 2beam compensation method (Andersen FH62-IR, $\beta$-attenuation). The meteorological measurements in Athens have been collected at the Patission station (prevailing wind directions: N 15.82\%, NNE 15.57\%, SSW 10.95\%, average wind speed: $2.8 \mathrm{~m} \mathrm{~s}^{-1}$ ) and in Thessaloniki at the Panorama station (prevailing wind directions: NNW 11.02\%, NE 10.39\%, SE $10.36 \%$, average wind speed: $\left.1.4 \mathrm{~m} \mathrm{~s}^{-1}\right)$.

\section{RESULTS AND DISCUSSION}

\subsection{Seasonal variation of $\mathrm{PM}_{10}$ monthly mean values}

The seasonal variation of the mean monthly concentrations at the two examined monitoring stations of the urban area of Athens for the 4-year period 2001-2004 are presented in Figure 1. The mean monthly concentrations at the central urban station of Athens, are clearly higher (mean monthly values ranging between 45 and $65 \mathrm{\mu g} \mathrm{m}^{-3}$ ) than the corresponding ones at the peripheral station. At the central urban station the minimum is observed in June and the maximum in November while at the peripheral station the highest values are observed during the spring and summer season (March to August). The minimum monthly value recorded at the peripheral station (Thrakomakedones) during spring and summer is $32 \mathrm{\mu g} \mathrm{m}^{-3}$ (in June).

In Figure 2 the mean monthly concentrations at the two examined monitoring stations of the urban area of Thessaloniki for the 4-year period 2001-2004 are presented. The average $\mathrm{PM}_{10}$ monthly mean values at the central urban station range between 50 and $85 \mu \mathrm{g} \mathrm{m}^{-3}$ throughout the year. The minimum is observed in July and the maximum in November. In the peripheral station of Thessaloniki the highest values are observed also in April-May, at $35-40 \mu \mathrm{g} \mathrm{m}^{-3}$ 
and the mean monthly summer values are comparable with the corresponding in Athens in the 30-35 $\mu \mathrm{g} \mathrm{m}^{-3}$ range. The winter values though are lower in the peripheral Athens station.

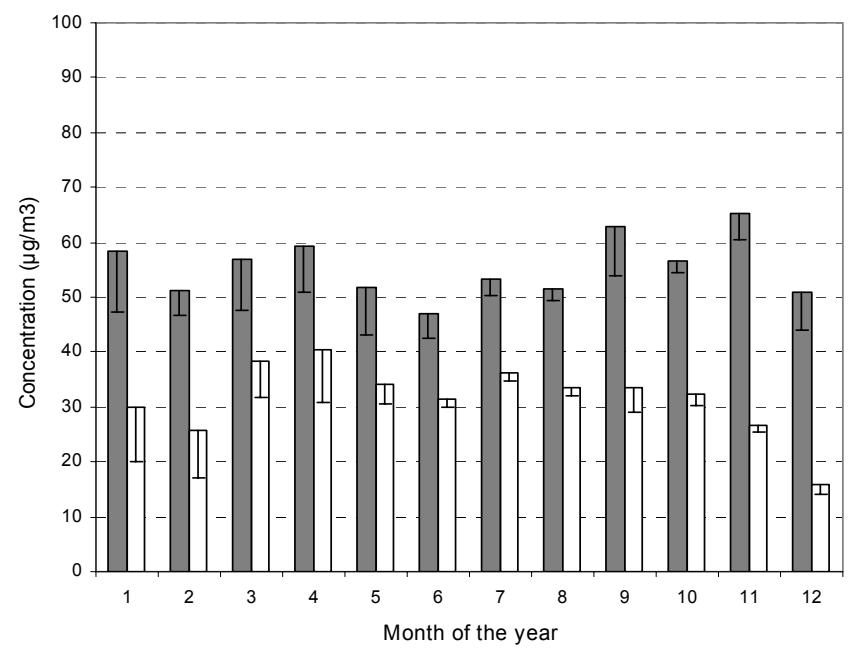

Figure 1. Mean monthly $\mathrm{PM}_{10}$ atmospheric concentrations in Athens, at a central urban station (Aristotelous, grey) and at a peripheral station (Thrakomakedones, white), for the 4-year period 2001-2004. Vertical bars indicate the standard deviations

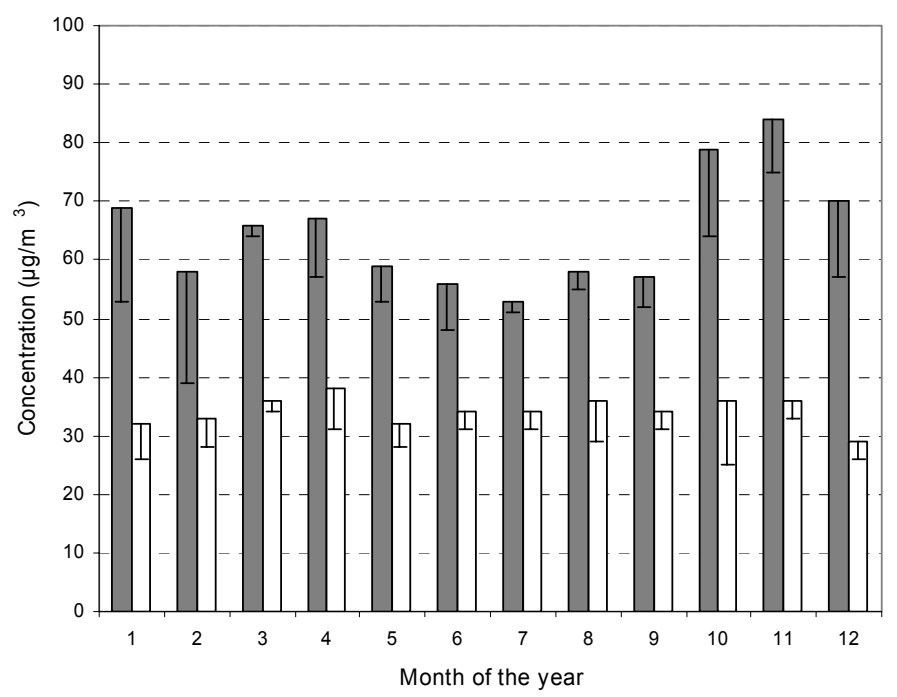

Figure 2. Mean monthly $\mathrm{PM}_{10}$ atmospheric concentrations in Thessaloniki, at a central urban station (Ag. Sophia, grey) and at a peripheral station (Panorama, white), for the 4-year period 2001-2004. Vertical bars indicate the standard deviations

As observed in both Figures 1 and 2 the seasonal variation of the urban stations is quite different than the corresponding seasonal variation pattern of the peripheral stations. At the central urban stations the average $\mathrm{PM}_{10}$ monthly mean values during the winter months (NDJF) are higher than during the summer months (MJJA), which is not observed for the peripheral stations. The observed difference between the urban and peripheral stations in spring and summer is about $15-20 \mu \mathrm{g} \mathrm{m}^{-3}$, while the corresponding difference for the autumn and winter months is about $25-40 \mu \mathrm{g} \mathrm{m}^{-3}$. It should be noticed that the variation pattern of the $\mathrm{PM}_{10}$ differences between urban and peripheral stations (low summer and high winter differences) is similar with the seasonal variation pattern of the concentrations of primary pollutants $\left(\mathrm{SO}_{2}, \mathrm{NO}_{x}, \mathrm{CO}\right)$ in the urban area of Athens (Kalabokas et al., 1999). The above observation suggests that the examination of the differences between urban and peripheral stations, could serve as a first approach in estimating the $\mathrm{PM}_{10}$ contribution originating only from local urban activities. 
It comes out from Figures 1-2 that at the central urban stations of both examined cities, the annual mean EU standard $\left(40 \mu \mathrm{g} \mathrm{m}^{-3}\right)$ is exceeded but also the measurements of the peripheral stations, which are significantly less influenced by the urban pollution sources than the central urban stations, approach this level especially during the warm period of the year. In the following paragraphs the daily and hourly values will be analyzed in order to determine the origin of the $\mathrm{PM}_{10}$ particles with more focus on the peripheral stations.

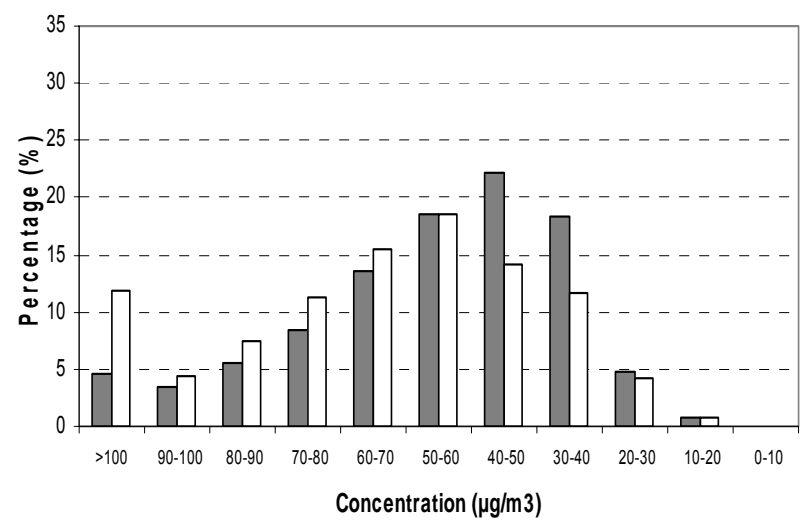

(a)

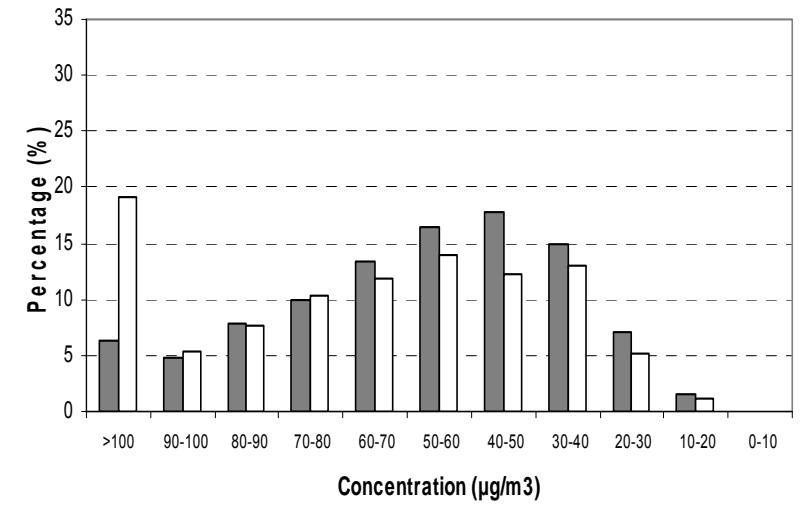

(b)

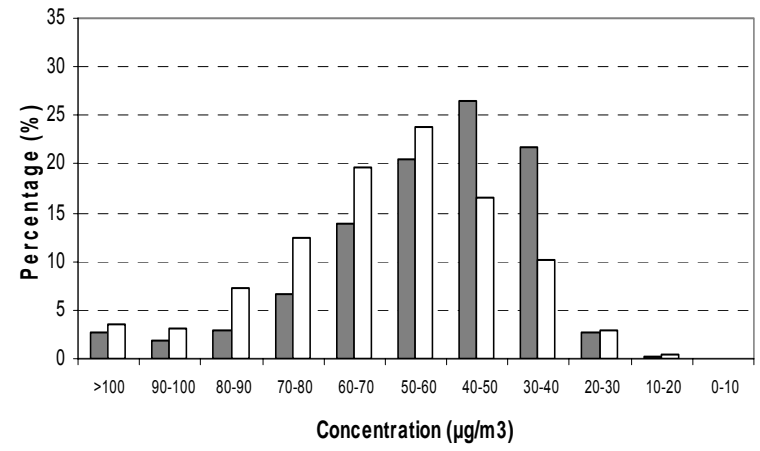

(c)

Figure 3. Distribution of $\mathrm{PM}_{10}$ atmospheric concentrations in the urban stations of Athens (Aristotelous, left) and Thessaloniki (Ag. Sophia, right), for the 4-year period 2001-2004

(a) All values, b) Cold semester, c) Warm semester)

\subsection{Distribution of $\mathrm{PM}_{10}$ daily mean values}

In Figures 3 and 4 the distribution of the daily mean $\mathrm{PM}_{10}$ atmospheric concentrations in the urban stations of Athens and Thessaloniki are presented for the whole year (Figures 3a, 4a), the cold semester (Figures 3b, 4b) and the warm semester of the year (Figures 3c, 4c). The distribution of the urban $\mathrm{PM}_{10}$ daily mean values show important differences between the Athens and the Thessaloniki stations especially for the cold semester of the year, when the percentage of daily mean concentrations exceeding $100 \mathrm{\mu g} \mathrm{m}^{-3}$ is significantly higher for 
Thessaloniki (Figure 3b). Concerning the warm semester of the year (Figures 3c, 4c), Athens shows higher percentage distribution values in the $30-50 \mu \mathrm{g} \mathrm{m}^{-3}$ range while Thessaloniki shows higher contributions in the 50-90 $\mu \mathrm{g} \mathrm{m}^{-3}$ range, which might imply different atmospheric processes controlling the $\mathrm{PM}_{10}$ air concentrations between the warm and the cold seasons. Daily averages higher than $90 \mu \mathrm{g} \mathrm{m}^{-3}$ are observed mainly during the cold semester of the year at the urban stations of both cities.

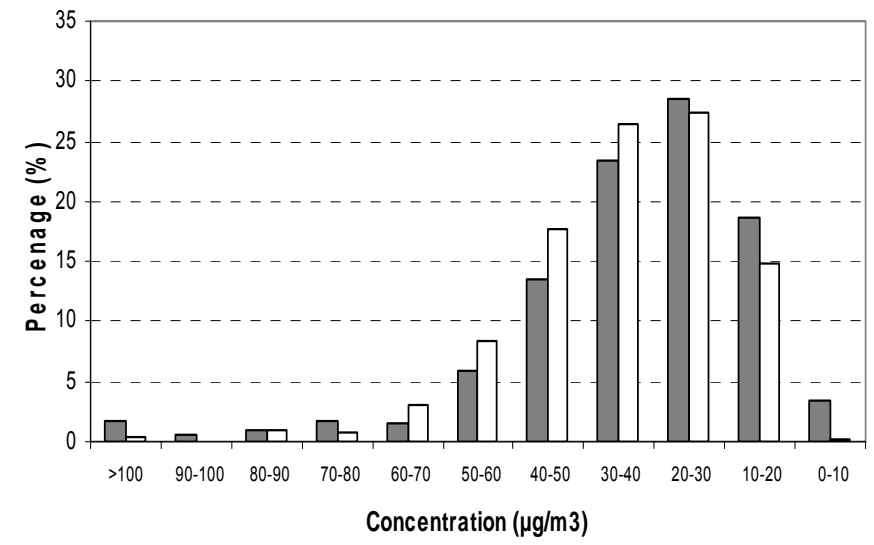

(a)

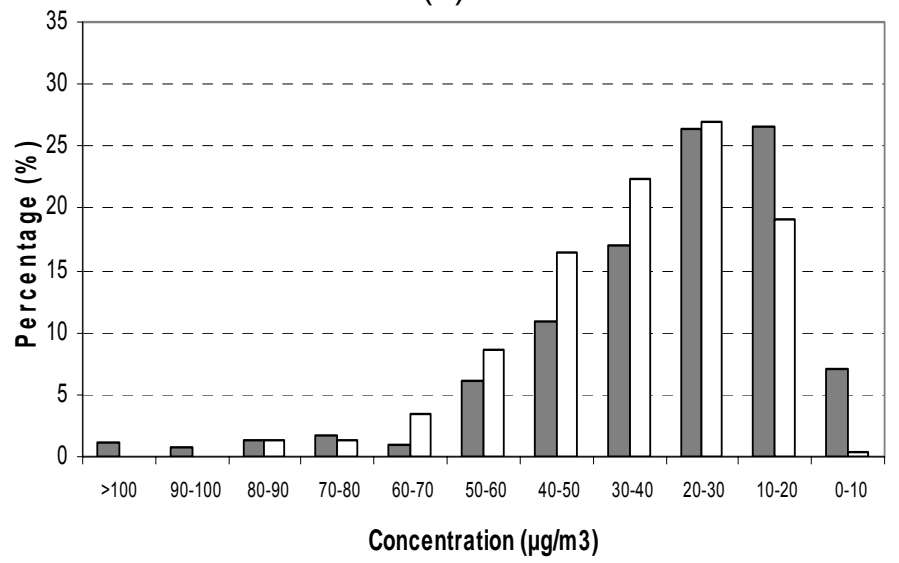

(b)

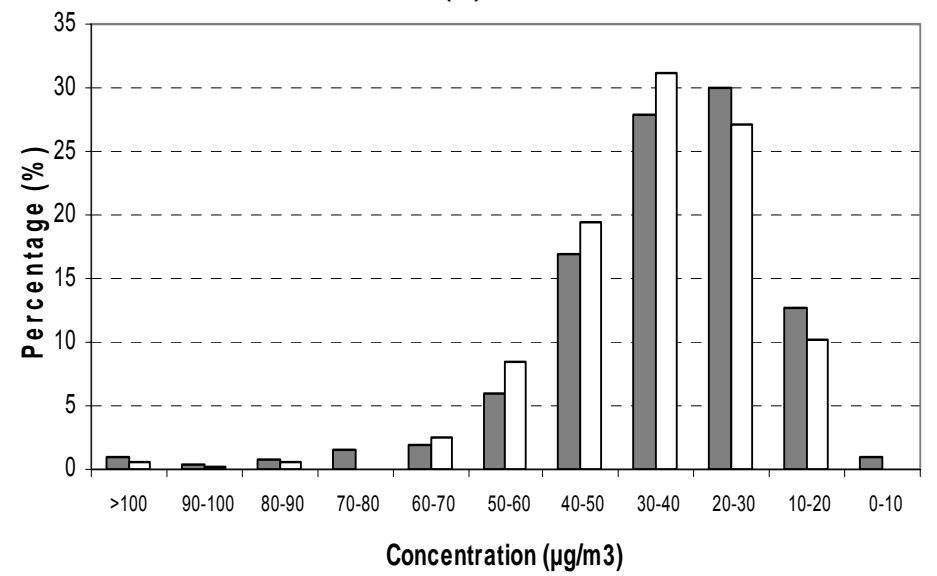

(c)

Figure 4. Distribution of $\mathrm{PM}_{10}$ atmospheric concentrations in the peripheral stations of Athens

(Thrakomakedones, left) and Thessaloniki (Panorama, right), for the 4-year period 20012004. (a) All values, b) Cold semester, c) Warm semester)

Regarding the EU daily mean standard $\left(50 \mu \mathrm{g} \mathrm{m}^{-3}\right.$ daily mean not to be exceeded more that 35 times in a year), it is massively exceeded at the central urban stations of both examined cities as the majority of the examined values are higher that the standard value (Urban 
Athens: $54 \%$, Urban Thessaloniki: $69 \%$ ). It is also remarkable (Figure 4) that the $50 \mu \mathrm{g} \mathrm{m}^{-3}$ daily mean value is frequently exceeded at the peripheral stations of both examined urban areas (Peripheral Athens: $12.4 \%$, Peripheral Thessaloniki: $13.3 \%$ ). In addition, the $\mathrm{PM}_{10}$ distribution curves at both peripheral stations are quite similar (Figure 4), indicating that comparable $\mathrm{PM}_{10}$ particle levels exist at the periphery of both examined urban areas, separated by a distance of about $500 \mathrm{~km}$, indicating comparable rural background $\mathrm{PM}_{10}$ levels. Another interesting feature in the distribution of the peripheral $\mathrm{PM}_{10}$ values in both cities is that while the most frequent concentrations during the cold semester of the year are in the 10$30 \mu \mathrm{g} \mathrm{m}^{-3}$ range (Figure $4 \mathrm{~b}$ ), they shift to the $20-50 \mu \mathrm{g} \mathrm{m}^{-3}$ range during the warm semester, indicating a change in the nature of particles between the two periods.

\subsection{Diurnal variation of $\mathrm{PM}_{10}$ hourly mean values}

In Figure 5 the diurnal variation of $\mathrm{PM}_{10}$ concentrations in the Athens urban area during the cold and the warm semester of the year are presented. The $\mathrm{PM}_{10}$ concentrations curves of the Athens peripheral stations of Thrakomakedones show a totally different behavior than the corresponding curves of the urban station of Aristotelous. The peripheral station shows a broad $\mathrm{PM}_{10}$ concentration maximum in the middle of the day (11:00 - 15:00) while the urban station shows a sharp peak in the morning $(7: 00-9: 00)$ coinciding with the morning traffic peak and a wider peak at night (21:00-02:00) when the nocturnal vertical stability conditions prevail. Another difference is that at the peripheral station the concentrations during the warm semester of the year are slightly higher than during the cold semester while in the urban station the opposite is observed especially during the morning and the evening peaks, which probably indicates the different nature of the measured $\mathrm{PM}_{10}$ particles during the cold and the warm seasons at the two examined sites with different pollution characteristics (urban peripheral). The summer increase at the peripheral stations might be attributed to the increase of the regional background $\mathrm{PM}_{10}$ levels, while at the central urban stations the summer decrease could be due to the corresponding decrease of the primary urban emissions. A similar pattern is observed in general in the diurnal $\mathrm{PM}_{10}$ variations of the warm and the cold semester of the year for the two examined Thessaloniki stations (Figure 6). At the urban station of Thessaloniki the concentrations during the cold semester are clearly higher than during the warm semester showing differences of about $15 \mu \mathrm{g} \mathrm{m}^{-3}$ in the afternoon and the evening hours. The corresponding difference in Athens is $5-10 \mu \mathrm{g} \mathrm{m}^{-3}$ and it is observed only during the morning and the late evening hours. At the peripheral station of Thessaloniki (Figure 6) the average diurnal $\mathrm{PM}_{10}$ concentrations during the warm semester shows in general slightly higher values than during the cold semester except for the afternoon hours (14:00 - 19:00). The diurnal variation patterns of the examined peripheral stations at both cities are quite comparable and their observed average diurnal concentration levels show broad midday peaks at the $40-45 \mu \mathrm{g} \mathrm{m}^{-3}$ level.

From the above analysis of $\mathrm{PM}_{10}$ atmospheric measurements, it seems that $\mathrm{PM}_{10}$ particles show characteristics of primary but also of secondary atmospheric pollutants. At first, the levels at the peripheral stations are lower than the corresponding ones at the urban stations, which is a primary pollutant characteristic, same as $\mathrm{NO}_{\mathrm{x}}$ or $\mathrm{SO}_{2}$ (Kalabokas et al., 1999). On the other hand the $\mathrm{PM}_{10}$ average value of the peripheral stations during the warm period of the year is higher (even slightly) than the corresponding average for the cold period and a broad maximum during the day is observed, which are characteristics observed forsecondary air pollutants like ozone (Kalabokas et al., 2000; Kalabokas et al., 2004). It is important though to mention that this slight summer increase at the peripheral stations occurs despite the corresponding decrease at the urban stations. The relatively higher concentrations during summer could be attributed to local secondary particle formation but also to the increased particle levels on regional scale associated with long-range transport. The variation characteristics of the $\mathrm{PM}_{10}$ seasonal average concentration levels together with the principle gaseous air pollutants $\left(\mathrm{SO}_{2}, \mathrm{NO}_{\mathrm{x}}\right.$, ozone) have been examined in detail for Athens in a previous study (Kalabokas et al., 2006) and are in agreement with the above remarks arising from the analysis of the $\mathrm{PM}_{10}$ diurnal profiles. The high $\mathrm{PM}_{10}$ levels at the peripheral stations while low primary pollutant concentrations are observed at the same time (Kalabokas et al., 2006) are strong indications that in the atmosphere of the urban areas of Athens and 
Thessaloniki there is a substantial amount of particles not originating directly from local urban activities. As reported in the literature there are some categories of $\mathrm{PM}_{10}$ particles either of natural or of anthropogenic origin (mainly in a secondary form), which can be transported over large distances and which could deteriorate the air quality even of large urban centers (Noone et al., 2003).

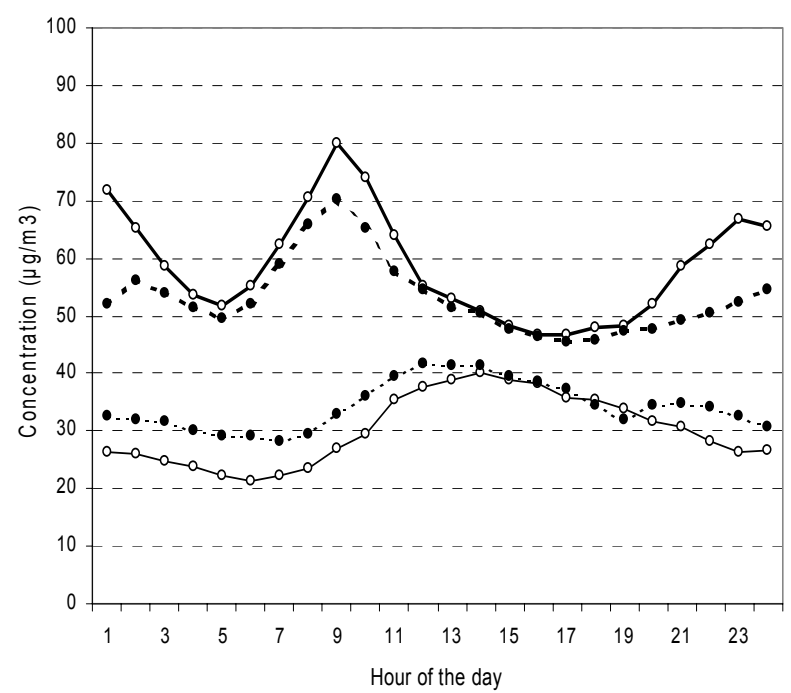

Figure 5. Diurnal variation of $\mathrm{PM}_{10}$ concentrations in Athens, at the central urban station of Aristotelous (bold solid line: cold semester, bold dashed line: warm semester) and the peripheral station of Thrakomakedones (solid line: cold semester, dashed line: warm semester), averaged over the 4-year period 2001-2004

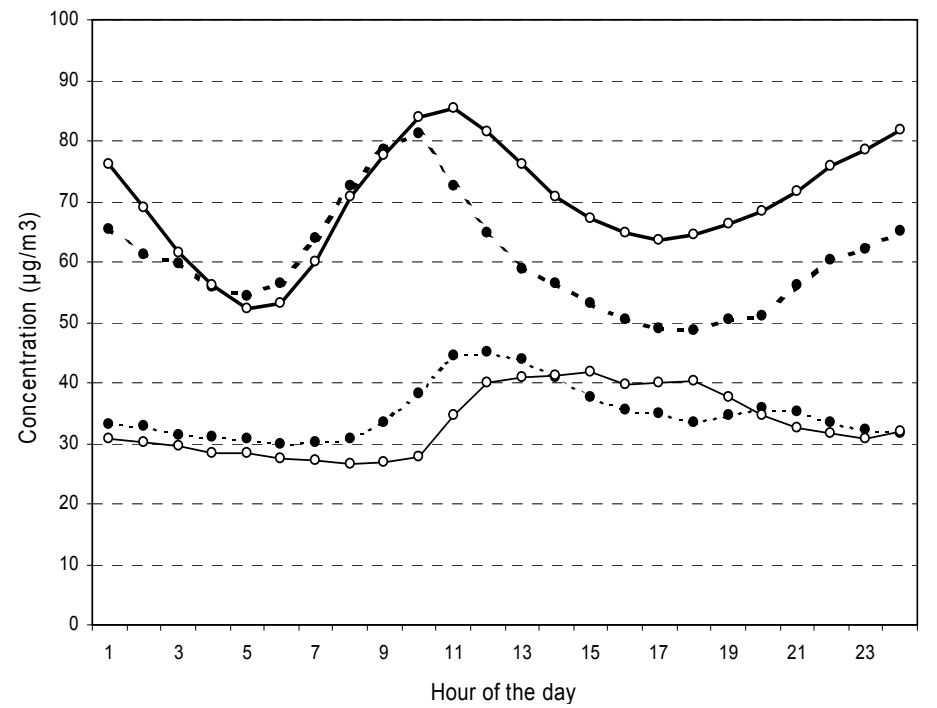

Figure 6. Diurnal variation of $\mathrm{PM}_{10}$ concentrations in Thessaloniki, at the central urban station of Ag. Sophia (bold solid line: cold semester, bold dashed line: warm semester) and the peripheral station of Panorama (solid line: cold semester, dashed line: warm semester), averaged over the 4-year period 2001-2004

\subsection{Scatter plots of urban versus peripheral $\mathrm{PM}_{10}$ daily mean values}

In order to check to what extend any increased regional background aerosol levels might influence significantly the recorded $\mathrm{PM}_{10}$ levels at the urban and the peripheral stations of both examined cities, the regression lines between the urban and the peripheral stations at each examined city are presented in Figures 7 and 8 . The monitoring stations at Thessaloniki show higher correlations especially for the warm semester of the year $\left(R^{2}=0.75\right.$; Figure $\left.8 c\right)$. The higher correlations for the Thessaloniki stations could be explained by the fact that it is a 
smaller urban area compared to Athens. It is clear though that a large part of the variability of $\mathrm{PM}_{10}$ concentrations is controlled by the rural background levels as well as the occasional dust pollution episodes occurring at a regional scale and associated with long-range transport of soil dust especially from the Sahara desert (Papayannis et al., 2005; Borge, 2007; Mitsakou et al., 2008; Grivas et al., 2008).

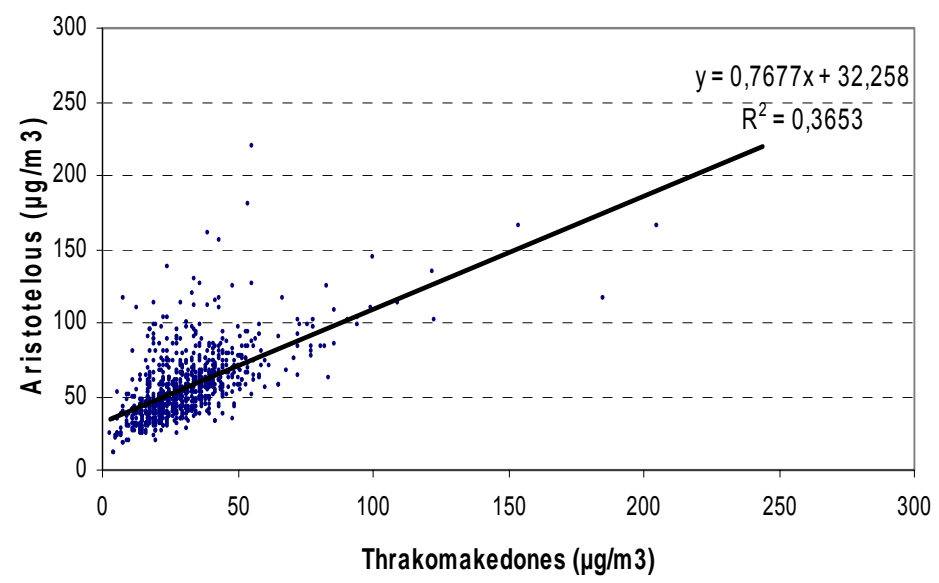

(a)

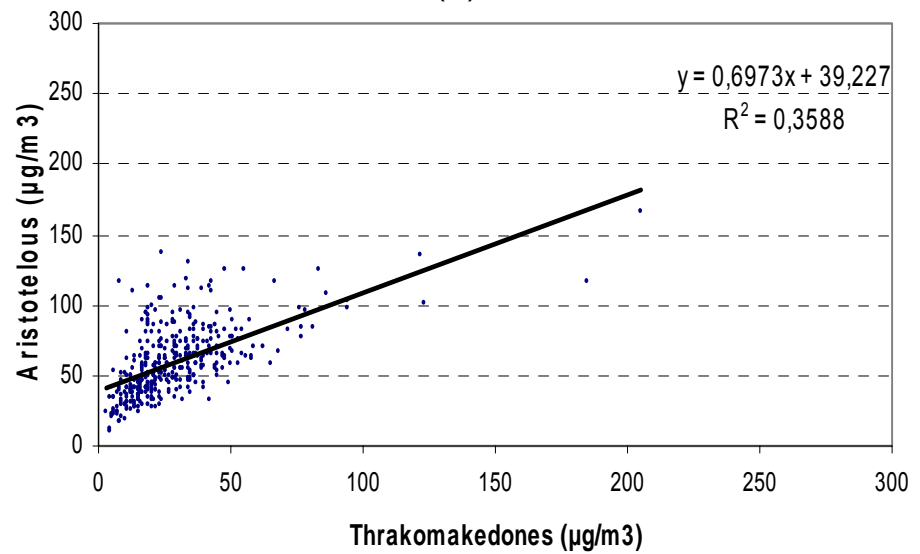

(b)

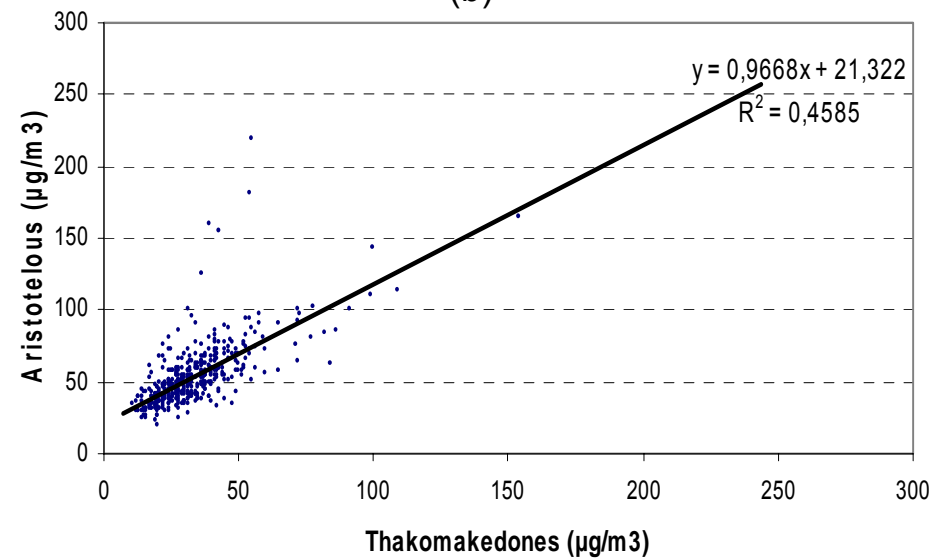

(c)

Figure 7. Scatter plot of $\mathrm{PM}_{10}$ daily values of the Athens monitoring stations: Aristotelous (Central Urban) versus Thrakomakedones (Peripheral). (a) All values, b) Cold semester, c) Warm semester) 


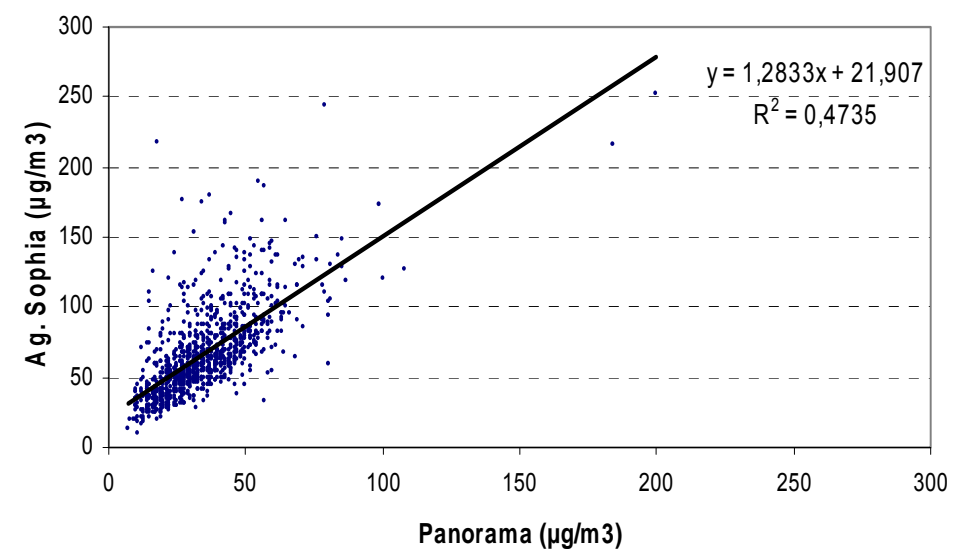

(a)

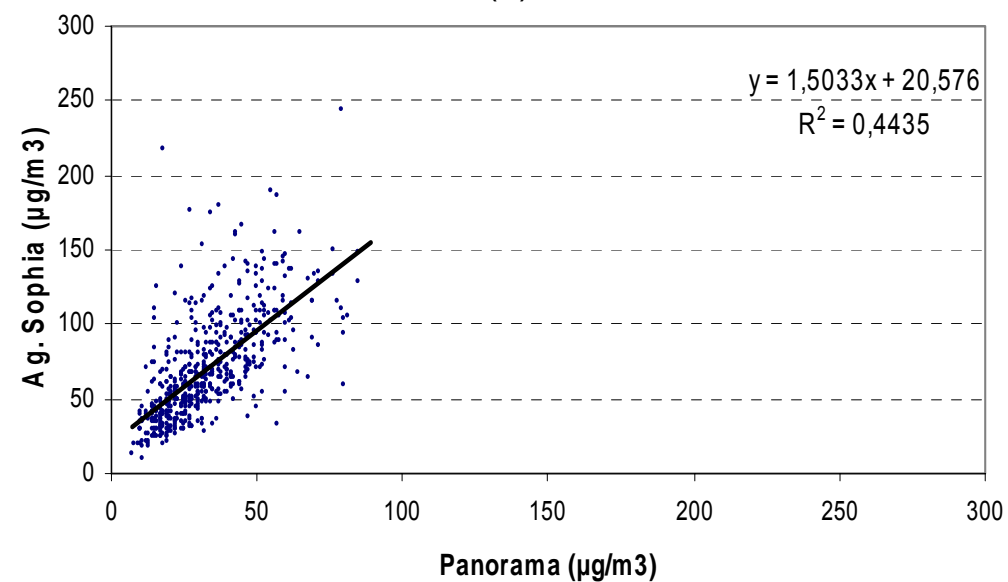

(b)

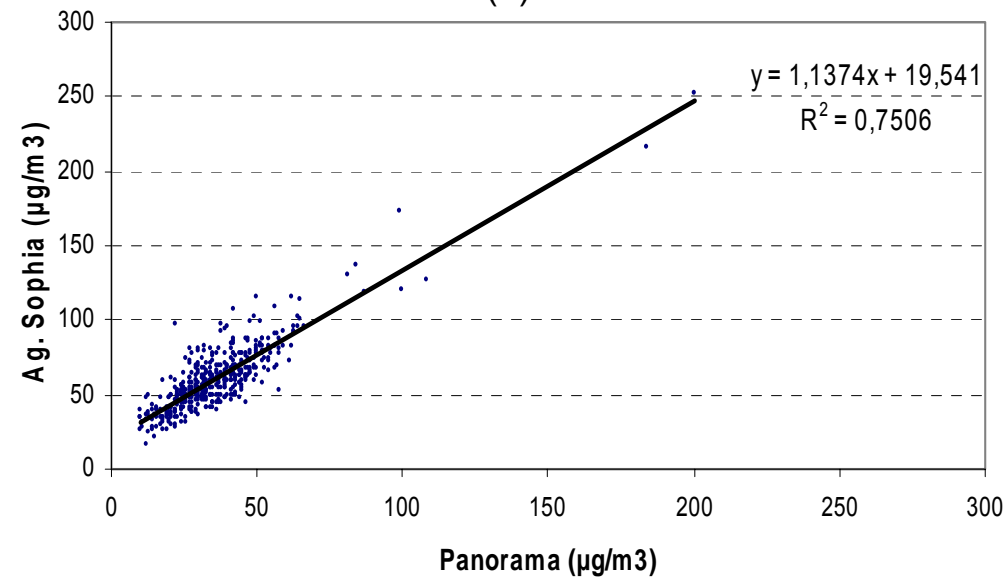

(c)

Figure 8. Scatter plot of $\mathrm{PM}_{10}$ daily values of the Thessaloniki monitoring stations: Agia Sophia (Central Urban) versus Panorama (Peripheral).

(a) All values, b) Cold semester, c) Warm semester)

The influence of the regional particulate pollution episodes and the rural background levels on the measured $\mathrm{PM}_{10}$ concentrations in the Athens and Thessaloniki urban areas seems to be stronger during the warm semester of the year as the corresponding slopes in the regression equations at both cities are close to 1 and the correlation coefficient $(R)$ attains its highest values (Figs. 7c, 8c). Athens seems to be more influenced by severe regional aerosol episodes as more days with very high concentrations at both the urban and the peripheral station are found. In addition in Athens (Fig. 7), the group of points combining high urban and low peripheral $\mathrm{PM}_{10}$ concentrations (on the left side of the figures) should be associated with intense local pollution episodes in the Athens urban area leading to secondary formation of 
urban aerosols, especially in summer (Fig. 7c). An approximation of the $\mathrm{PM}_{10}$ levels attributed to the city activities could be given by the intercepts of the corresponding regression equations. If all values are taken into account the graphical estimation of the urban contributions at both cities are $32 \mu \mathrm{g} \mathrm{m}^{-3}$ and $22 \mu \mathrm{g} \mathrm{m} \mathrm{m}^{-3}$ respectively (Figs. $7 \mathrm{a}$, 8a), while the local urban contribution at both cities is estimated to be around $20 \mu \mathrm{g} \mathrm{m}^{-3}$ during the warm semester (Figs. 7c, 8c). The above observation leads also to the conclusion that a significant part of the levels measured at the centers of the examined urban areas (about $50 \%$ ) and the almost all of the measured concentration levels at the peripheral stations are controlled by the rural regional background levels.

\subsection{Peripheral and Background $\mathrm{PM}_{10}$ daily mean values}

In order to obtain a more accurate determination of the rural background levels of the surrounding area, the Directorate of Air Pollution and Noise Control of the Ministry for the Environment performed daily $\mathrm{PM}_{10}$ measurements during the year 2006 in the rural station of Aliartos, located about $100 \mathrm{~km} \mathrm{NW}$ of Athens in the Copais Plain and participating in the EMEP network. In total 86 daily measurements, using the gravimetric method (EN 12341:1999 Standard), have been performed during the January-June 2006 and the November - December 2006 period. The comparability of this method with the b-attenuation method has been reported in the literature (GMBI report, 2000). The average $\mathrm{PM}_{10}$ rural value in Aliartos is shown in Table 1 together with the average daily values for the corresponding days in the peripheral stations of Thrakomakedones (Athens) and Panorama (Thessaloniki) as well as in the Athens urban station of Aristotelous (the Ag. Sophia station in Thessaloniki was out of service in 2006). It comes out that the $\mathrm{PM}_{10}$ average rural levels in Aliartos (32 $\mu \mathrm{g}$ $\mathrm{m}^{-3}$ ) are quite close to the corresponding average values of the peripheral stations in Athens and Thessaloniki and these levels are about the half of the corresponding urban levels.

Table 1. $\mathrm{PM}_{10}$ daily average values $\left(\mu \mathrm{g} \mathrm{m}^{-3}\right)$ of 86 daily measurements in 2006 (January-June and November-December) at the rural station of Aliartos (Central Greece), using the gravimetric method, and the corresponding $\mathrm{PM}_{10}$ daily averages at the peripheral station of Thrakomakedones (Athens), the peripheral station of Panorama (Thessaloniki) and the urban station of Aristotelous (Athens), using the b-attenuation method

\begin{tabular}{lc}
\hline Monitoring stations & $\mathbf{P M}_{\mathbf{1 0}}$ daily means \\
\hline $\begin{array}{l}\text { Aliartos } \\
\text { (Rural Central Greece) }\end{array}$ & $32 \pm 17$ \\
\hline $\begin{array}{l}\text { Thrakomakedones } \\
\text { (Peripheral Athens) }\end{array}$ & $26 \pm 19$ \\
\hline $\begin{array}{l}\text { Panorama } \\
\text { (Peripheral Thessaloniki) }\end{array}$ & $31 \pm 13$ \\
\hline $\begin{array}{l}\text { Aristotelous } \\
\text { (Urban Athens) }\end{array}$ & $59 \pm 25$ \\
\hline
\end{tabular}

The above reported results, concerning the average values of the rural background $\mathrm{PM}_{10}$ levels are comparable with the corresponding levels reported in other Mediterranean countries like Italy and Spain (about $30 \mathrm{\mu gm}^{-3}$ and $20 \mathrm{\mu g} \mathrm{m}^{-3}$ respectively, EMEP report, 2007). They are also in good agreement with the findings of similar studies carried out in the city of Volos in Central Greece (Kalabokas et al., 2005), as well as at urban area of Heraklion and the rural site of Finokalia in Crete Crete (Gerasopoulos et al., 2006; Eleftheriadis et al., 2006), indicating comparable rural background $\mathrm{PM}_{10}$ levels in Eastern Greece along the North-South axis. As reported in the literature the high $\mathrm{PM}_{10}$ rural background levels over the Aegean area could be due to a variety of sources such as: regional episodes of dust transport from desert areas, sea-spray and secondary aerosol formation either from biogenic or anthropogenic emissions as well as long-range pollution transport (Papayannis et al., 2005; Gerasopoulos et al., 2006; Eleftheriadis et al., 2006; Borge, 2007; Mihalopoulos and Chaloulakou, 2008; Mitsakou et al., 2008; Grivas et al., 2008). The relative contribution of each of the above factors could be determined by chemical analysis of $\mathrm{PM}_{10}$ particles and some relevant studies have been already reported (Manoli et al., 2002; Bardouki et al., 2003; 
Manalis 2005; Valavanidis 2006). For a better and more accurate determination of the origin of atmospheric $\mathrm{PM}_{10}$ particles, many more particle chemical analysis studies should be carried out at various sites with different pollution characteristics

\section{CONCLUSIONS}

The mean monthly $\mathrm{PM}_{10}$ concentrations at the central urban stations in Athens and Thessaloniki, Greece, are on the average about twice as high in comparison to the corresponding concentrations at the examined peripheral stations.

The distributions of the $\mathrm{PM}_{10}$ daily mean concentrations at the central urban stations in Athens and Thessaloniki show significant exceedances of the EU air quality standards. The percentage of daily mean concentrations exceeding $100 \mathrm{\mu g} \mathrm{m}^{-3}$ is higher for Thessaloniki while the $30-50 \mu \mathrm{g} \mathrm{m}^{-3}$ range shows higher contributions in Athens. The corresponding $\mathrm{PM}_{10}$ distribution curves for the peripheral stations are quite similar indicating that comparable rural background $\mathrm{PM}_{10}$ levels exist in the surrounding areas of both examined cities. Also at both peripheral stations the most frequent concentrations during the cold semester of the year are in the $10-30 \mu \mathrm{g} \mathrm{m}^{-3}$ range and they shift to the $20-50 \mu \mathrm{g} \mathrm{m}^{-3}$ range during the warm semester indicating a change in the nature of particles between the two periods.

From the analysis of the diurnal variation of $\mathrm{PM}_{10}$ concentrations during the cold and the warm semester of the year, it comes out that $\mathrm{PM}_{10}$ particles shows mixed characteristics compared with the other primary and secondary pollutants. The primary pollutant characteristic is that the levels at the peripheral stations are lower than the corresponding ones at the urban stations. On the other hand the $\mathrm{PM}_{10}$ average value of the peripheral stations during the warm period of the year is slightly higher than the corresponding average for the cold period, which is a characteristic observed for ozone, indicating the existence of important rural background aerosol levels.

The examination of the scatter-plots of the daily mean values of the central urban and the peripheral stations shows that the influence of the rural background levels and also the regional aerosol episodes on the measured $\mathrm{PM}_{10}$ concentrations in the Athens and Thessaloniki urban areas is stronger in Athens and during the warm semester of the year.

Additional daily measurements at a rural station in Central Greece (Aliartos) give $\mathrm{PM}_{10}$ average values in the range around 30 , comparable to the corresponding average $\mathrm{PM}_{10}$ values of the peripheral stations in Athens and Thessaloniki. These values, indicative of the rural background $\mathrm{PM}_{10}$ levels of the surrounding area, are quite significant in respect to the current EU $\mathrm{PM}_{10}$ standard for the average annual value $\left(40 \mu \mathrm{g} \mathrm{m}^{-3}\right)$. This remark underlines the difficulties of the examined urban areas to comply with the EU legislation as the local pollution abatement actions may not be adequate with such high regional background $\mathrm{PM}_{10}$ levels of either natural or anthropogenic origin transported over long distances.

\section{ACKNOWLEDGEMENTS}

This work was supported by the EU funded project HEREPLUS (HEalth Risk from Environmental Pollution Levels in Urban Systems).

\section{REFERENCES}

Bardouki H., Liakakou H., Economou J., Sciare J., Smolik J., Zdimal V., Eleftheriadis K., Lazaridis M., Dye C. and Mihalopoulos N. (2003) Chemical composition of size-resolved atmospheric aerosols in the eastern Mediterranean during summer and winter, Atmosph. Environ., 37, 195-208.

Borge R., Lumbreras J., Vardoulakis S., Kassomenos P. and Rodriguez E. (2007) Analysis of long-range transport influences on urban $\mathrm{PM}_{10}$ using two-stage atmospheric trajectory clusters, Atmosph. Environ., 41, 4434-4450.

Buseck P.R. and Schwartz S.E. (2006) Tropospheric aerosols. In: The Atmosphere (Ed. R.F. Keeling). Treatise on Geochemistry (Vol. 4). Elsevier.

Chaloulakou A., Kassomenos P., Spyrellis N., Demokritou P. and Koutrakis P. (2003) Measurements of $\mathrm{PM}_{10}$ and $\mathrm{PM}_{2.5}$ particle concentrations in Athens, Greece, Atmosph. Environ., 37, 649-660. 
Chaloulakou A., Kassomenos P., Grivas G. and Spyrellis N. (2005) Particulate matter and black smoke concentration levels in central Athens, Greece, Environment International, 31, 651659.

Dockery D.W., Schwartz J. and Spengler J.D. (1992) Air pollution and daily mortality: association with particulates and acid aerosols, Environ. Res., 59, 362-373.

EC (1999) EU Directive 1999/30/EC, Official Journal of the European Communities No L 163, p41.

EEA (2006) Air pollution at street level in European cities. EEA Technical report No 1/2006, ISBN 92-9167-815-5, ISSN 1725-2237, European Environment Agency, Copenhagen, Denmark

EMEP (2007) Particulate Matter Assessment Report, EMEP/CCC-Report 8/2007, NILU, Norway

Eleftheriadis K., Colbeck I., Housiadas C., Lazaridis M., Mihalopoulos N., Mitsakou C., Smolík J., and Zdímal V. (2006) Size distribution, composition and origin of the submicron aerosol in the marine boundary layer during the eastern Mediterranean "SUB-AERO" experiment, Atmosph. Environ., 40, 6245-6260.

Flocas H, Kelessis A., Helmis C., Petrakakis M., Zoumakis N. and Pappas K. (2009) Synoptic and local scale atmospheric circulation associated with air pollution episodes in an urban Mediterranean area, Theoretical and Applied Climatology, 95, 265 - 277.

Finlayson-Pitts B.J. and Pitts J.N.Jr. (2000) Particles in the Troposphere. In: Chemistry of the Upper and Lower Atmosphere, Academic Press, 349-423.

Gerasopoulos E., Kouvarakis G., Babasakalis P., Vrekoussis M., Putaud J.P. and Mihalopoulos N. (2006) Origin and variability of particulate matter (PM10) mass concentrations over the Eastern Mediterranean, Atmosph. Environ., 40, 4679-4690.

GMBI (2000) Joint Ministerial Gazette of the Federal Ministries, GMBI No. 60, p. 1195

Grivas G., Chaloulakou A. and Kassomenos P. (2008) An overview of the PM10 pollution problem, in the Metropolitan Area of Athens, Greece. Assessment of controlling factors and potential impact of long-range transport, Sci. of Tot. Environ., 389, 165 - 177.

Helmis C.G., Tombrou M., Asimakopoulos D.N., Soilemes A., Gusten H., Moussiopoulos N. and Hatzaridou A. (1997) Thessaloniki 91 field measurement campaign. I. Wind field and atmospheric boundary layer structure over greater Thessaloniki area under light background flow, Atmosph. Environ., 31, 1101-1114.

IPCC: Intergovernmental Panel on Climate Change, Climate Change (2001): The Scientific Basis: Contribution of Working Group I to the Third Assessment Report of the Intergovernmental Panel on Climate, edited by: Houghton, J. T., Ding, Y., Griggs, D. J., et al., Cambridge Univ. Press, New York, 2001.

Kalabokas P. and Bartzis G. (1998) Photochemical air pollution characteristics at the station of the NCSR-Demokritos, during the MEDCAPHOT-TRACE campaign, Greece (August 20thSeptember 20th, 1994), Atmosph. Environ., 32, 2123-2139.

Kalabokas P.D., Viras L.G., Repapis C.C. (1999) Analysis of the 11-year record (1987-1997) of air pollution measurements in Athens, Greece. Part I: Primary pollutants, Global Nest: The Intern. Journal, 1(3), 157-167.

Kalabokas P.D. and Repapis C.C. (2004) A climatological study of rural surface ozone in Central Greece, Atmosph. Chem. Phys., 4, 1139-1147.

Kalabokas P.D., Sideris G., Christolis M. and Markatos N. (2005) Analysis of air quality measurements in Volos, Greece (in Greek). Proceedings of the $5^{\text {th }}$ International Exposition and Conference for the Environmental Technology (HELECO 05), Athens, Greece.

Kalabokas P.D., Adamopoulos A.D., Chronopoulos G. and Viras L.G. (2006) A study on the characteristic variations of $\mathrm{PM}_{10}$ atmospheric concentrations in Athens, Fres. Environ. Bul., 15, 846-852.

Kanakidou M., Tsigaridis K., Dentener F.J. and Crutzen P.J. (2000) Human activity enhanced formation of organic aerosols by biogenic hydrocarbon oxidation, J. Geophys. Res., 105, 9243-9254.

Katsouyanni K., Touloumi G., Spix C., Schwartz J., Balducci F., Medina S., Rossi G., Wojtyniak B., Sunyer J., Bacharova L., Schouten J.P., Ponka A. and Anderson H.R. (1997) Short term effects of ambient sulphur dioxide and particulate matter on mortality in 12 European cities: results from time-series data from the APHEA project, BMJ, 314, 1658-1663.

Kassomenos P., Kotroni V. and Kallos G. (1995) Analysis of climatological and air quality observations from Greater Athens Area, Atmosp. Environ., 29, 3671-3688. 
Kassomenos P., Flocas H.A., Lykoudis S. and Skouloudis A.N. (1998) Spatial and temporal characteristics of the relationship between air quality status and mesoscale circulation over an urban Mediterranean basin, The Science of the Total Environment, 217, 37-57.

Kelessis A.G., Zoumakis N.M., Petrakakis M.J. and Vosniakos F.K. (2002) Air pollution levels in Thessaloniki, Greece, Journ of Environ. Protection and Ecology, 3, 779-787

Kelessis A.G., Petrakakis M.J., Tzoumaka P.N., Tsougas M.A., Tzourelis G.A. and Zoumakis N.M. (2006) $\mathrm{PM}_{2.5}$ Concentration Levels in Urban Thesaloniki, Journal Fresenius Environmental Bulletin, 15(8b), 853-858.

Kourtidis K.A., Ziomas I., Zerefos C., Kosmidis E., Symeonidis P., Christophilopoulos E., Karathanassis S. and Mploutsos A. (2002) Benzene, toluene, ozone, NO and SO measurements in an urban street canyon in Thessaloniki, Greece, Atmosph. Environ., 36, $5355-5364$.

Lippman M. (1989) Background on health effects of acid aerosols, Environmental Health Perspectives, 79, 3-7.

Manalis N., Grivas G., Protonotarios V., Moutsatsou A., Samara C. and Chaloulakou A. (2005) Toxic metal content of particulate matter $\left(\mathrm{PM}_{10}\right)$, within the Greater Area of Athens, Chemosphere, 60, 557-566.

Mantis H., Repapis C., Zerefos C. and Ziomas J. (1992) Assessment of the potential for Photochemical air pollution in Athens: A comparison of emissions and air pollutant levels in Athens with those in Los Angeles, J. Appl. Met., 31, 1467-1476.

Manoli E., Voutsa D. and Samara C. (2002) Chemical characterization and source identification/apportionment of fine and coarse air particles in Thessaloniki, Greece, Atmosph. Environ., 36, 949-961.

Mihalopoulos N. and Chaloulakou A. (2008) Origin and factors controlling levels of particulate matter in urban and rural locations in Greece, $9^{\text {th }}$ Conference of Meteorology, Climatology and Atmospheric Physics (COMECAP), 28-31 May 2008, Thessaloniki, Greece, pp.727-734.

MinEnv report, 2002. Atmospheric pollution in Athens - 2001. Directorate of air pollution and noise control, Ministry of Environment (in Greek).

Mitsakou C., Kallos G., Papantoniou N., Spyrou C., Solomos S., Astitha M. and Housiadas C. (2008) Saharan dust levels in Greece and received inhalation doses, Atmos. Chem. Phys., 8, 7181-7192.

Noone K., Baltensperger U., Flossman A., Fuzzi S. et al. (2003) Tropospheric aerosols and clouds. In: Towards cleaner air for Europe -Science, tools and applications. Part 1: Results from the EUROTRAC-2, Synthesis and integration report, (Ed. P. Midgley et al.,), Margaf Publications.

Papayannis A., Balis D., Amiridis V., Chourdakis G., Tsaknakis G., Zerefos C., Castanho A.D.A., Nickovic S., Kazadzis S. and Grabowski J. (2005) Measurements of Saharan dust aerosols over the Eastern Mediterranean using elastic backscatter-Raman lidar, spectrophotometric and satellite observations in the frame of the EARLINET project. Atmos. Chem. Phys., 5, 2065-2079.

Schwela D., Morawska L. and Kotzias D. (2002) Guidelines for concentration and exposureresponse measurements of fine and ultrafine particulate matter for use in epidemiological studies. EUR 20238, 184 pp.

Valavanidis A., Fiotakis K., Vlahogianni T., Bakeas E.B., Triantafillaki S., Paraskevopoulou V. and Dassenakis M. (2006) Characterization of atmospheric particulates, particle-bound transition metals and polycyclic aromatic hydrocarbons of urban air in the centre of Athens (Greece), Chemosphere, 65, 760-768.

Viras L. and Siskos P. (1992) Air pollution by gaseous pollutants in Athens, Greece. In: Gaseous pollutants: Characterization and Cycling, (Ed.) J.O. Nriagu, J. Wiley \& Sons, pp. 271-305.

Warneck P. (2000) The atmospheric aerosol. In: Chemistry of the Natural Atmosphere, International Geophysics Series (Vol. 71), Academic Press, 346-450.

Ziomas I. (1998) The Mediterranean Campaign of Photochemical Tracers-Transport and Chemical Evolution (MEDCAPHOT-TRACE): An outline, Atmosph. Environ., 32, 2045-2054. 